Stellenbosch Theological Journal 2015, Vol 1, No 2, 791-794

DOI: http://dx.doi.org/10.17570/stj.2015.v1n2.br03

Online ISSN 2413-9467 | Print ISSN 2413-9459

2015 (c) Pieter de Waal Neethling Trust

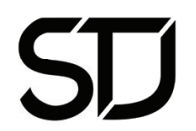

\title{
Myers, Benjamin
}

\section{Christ the Stranger: The theology of Rowan Williams}

2012, London-New York: T \& T Clark

ISBN: 9780567562364

Reviewed by Khegan M Delport

Boccaccio once theorised (in his Life of Dante) that theology could be accurately described as 'poetry' about God. However, one does not always get the impression when reading theologians that such a connection is so obvious. And yet there are Christian writers who have sought to bring together the concerns of skilled writing and communication. One only has to remember Augustine's consummate level of Latin dexterity, or Calvin's influence on French prose writing, or Tyndale's translation of Bible to know that the relation between form and content, between the concrete and the evocative is by no means alien to the tradition of spiritual and theological writing.

It is for this reason that Benjamin Myers' descriptive and interpretative essay on Rowan Williams is particularly admirable. Besides being a wellresearched and readable work, it is filled with a good amount of apercus and insightful bon mots regarding key aspects of Williams' theology, such that in addition to being an accessible work, it is also an eminently quotable one as well. Some examples will suffice: regarding Williams' theological method he states in the Preface ( $\mathrm{p} \mathrm{xi}$ ) that theology in Williams' view is 'not a private table for one but a rowdy banquet for those who gather, famished and thirsty, around Christ'. The overtones of theological dialogue and Eucharistic communion are clearly evident here, expressing in nuce Williams' fundamental hermeneutical orientation, consistent throughout his oeuvre. This is reiterated again, towards the end of the book (pp119-120), when he writes (again concerning Williams' theological methodology) that his 'theology is not so much an orderly arrangement of themes as an assemblage of discrete textual performances, a written ensemble, a 
disparate set of experiments with the imaginative possibilities of a living spiritual tradition'. Underlying this method, it should be said, is not a cheap relativism but an attempt to glimpse reality as it $i s$, not merely as we would like it to be. Such a disposition is tied to Williams' own 'poetic sensibility' as well as his thoughts on language since, to quote Myers again ( $\mathrm{p} 2$ ), 'The poet is someone who looks at language so closely that it becomes new, so that what was always familiar now seems utterly singular and arresting. Our normal perceptions are dim and dreamlike, but the poet rouses us to attention - not really to see something new, but to see anew what was right there in front of us all along'. This statement also provides illumination regarding the title of the book: for Williams, the presence of the divine within the story of Christ, as narrated and performed in the church's life, is something that has to be experienced as strange, as something 'transcendent' in relation to our common assumptions regarding what divinity must be like. And it is the strangeness of such a divine presence that underlies Williams' own penchant for negative theology, his style of critical engagement, and his habit of looking at the world so intently that it becomes 'remote and unfamiliar' (p 1).

Regarding the main text and the layout, Myers opts for single word titles, each relating to a specific aspect of Williams' theology (viz. 'Sociality', 'Tragedy'. 'Language', 'Boundaries', 'Tradition', 'Growth', 'Mission', 'Saints', 'Desire', 'Hope', 'Prayer', 'Fantasy', 'Renunciation', and 'Writing'), punctuated with a Prologue, Interlude and Epilogue. Again, one can find lapidary formulations of Williams' various positions throughout the substance of Myers' essay. For example, regarding Williams' notions of sociality (heavily inflected by Russian Orthodox emigré thinkers), Myers says that 'we are most human when we are cracked, when each self-bleeds out into the lives of others' ( $p$ 17). For Williams, as Myers describes, the mysteriousness of personhood, and its fragmented quality, challenges any notion of the self-enclosed human ego or libido dominandi. Another great summary can be referenced, in relation to the notion of 'tradition' (here echoing the language of Wittgenstein), where he says that for Williams 'orthodoxy lies not in any conceptual tidiness but in a constantly expanding network of interpretative resources in which the 'raggedness' of Christian language is retained. Orthodoxy is messy, like real life' (p. 48). Or, in the wonderful chapter on 'Saints' we again can find simple insights 
containing weighted importance, such as 'We learn most about human beings not from pale mediocre cases, but from an aberration, the strange and unnerving spectacle of a holy life' ( $p$ 73). Or 'Holiness is not the self's erasure, but its intensification...Saints are not those who cultivate their own self-abnegation; they are engaged in the honest and forgetful business of giving themselves freely and receiving from others'. And this is because, as Myers suggests (apropos Williams), 'The ego is displaced by regarding it lightly, by treating it with reckless enjoyment, as though it were a gift' ( $p$ 75-76). One could quote many more beautifully precise commentaries, but enough has been said to justify my contention.

Nonetheless (here voicing a minor criticism) it could be suggested that with the desire for lyrical expression comes the risk that we might fall into impreciseness and potential vagaries. One example within the book is Myers' linking of tragedy to the divine life. Before this comment is made however, I should say that Myers' chapter on tragedy has been particularly helpful in giving direction to my own work, and therefore is thoroughly appreciated, since little has been written on Williams' own position in relation to tragedy. However, when he states that 'If tragedy means a total lack of completion and consolation, then it is hard to avoid concluding that there is something very like a tragedy going on forever between the persons of the trinity' ( $p$ 112), I would want to add a word of caution. Though it would take us too far afield to discuss the theory of divine self-exposure explicated in Williams' theology (the particular concern of Myers in the above quote), it is suffice to say that Williams' own trinitarian theology avoids imposing finite, human dramas of personality onto the divine life, or anything that will obfuscate the orthodox notion of divine simplicity and impassibility (in the sense of being subject to negative 'passions'). One only has to read his article 'God' (In: David F. Ford, Ben Quash, Janet Soskice (eds.) Fields of Faith: Theology and Religious Studies for the Twentieth Century (Cambridge: Cambridge University Press 2005), pp 7589) to confirm his position on this question. Admittedly, Myers' language is taking its cue from Williams' own Liddon Lectures (1998), published as A Margin of Silence: The Holy Spirit in Russian Orthodox Theology (Québec: Éditions dus Lys Vert, 2008), which does use some of Bulgakov's language in this regard; but Williams is immediately concerned to distance this 'potent mythology' (A Margin of Silence, p 23) from any literalness or unorthodox 
implications. Saying all of this however is only a small criticism in light of an all-round commendable work of scholarship and writing, one which I thoroughly recommend and endorse for the future study of this great Christian thinker. 